\title{
Special Issue Editorial: The Impact of Globalization for Adult Education and Higher Education
}

\author{
Mary Gene Saudelli and Dolana Mogadime \\ Guest Editors \\ Brock University
}

This special issue 'The Impact of Globalization for Adult Education and Higher Education' was inspired by Sharan Merriam's visit in 2011 to Brock University during which she delivered the inaugural address in the Faculty of Education's "Distinguished Speaker Lecture Series." Her lecture was entitled, "Globalization: Challenges and Opportunities for Adult Education." As the editors of this special issue, we sought manuscripts that considered the question: How does globalization play out within the practice of teaching and research in adult and higher education?

Several themes are present in the articles featured in this special issue. Transnational sites of oppressions are multifaceted whether they are based on the impact of multinational corporations, or global migrations in search of a better livelihood. Today's globalized, interconnected, and financialized times bear consequences for adults who are deserving of education programs that are responsive to their diverse realities, which has a profound impact on adult and higher education. The tensions over the nature of what adult education is and the delivery of culturally responsive approaches that include indigenous concerns and ways of knowing are emphasized throughout the articles featured in this special issue.

\section{The Special Issue Manuscripts}

Roger Boshier presents a narrative study of an eminent educator Yao Zhongda, in "Mao Was My Neighbour: Yao Zhongda and the 'Opening' of Chinese Adult Education." Yao was the Chief of the Bureau of Workers' and Peasants Education. Regardless of the fact that Yao is an important figure in adult education to many foreigners, few in China are aware of him or his salience to adult education in China. Boshier's paper captures some of the details of Yao's biography from his voice, and reflects on what it means for 21 st century China and adult education.

Amanda Benjamin, Melissa White, Mary MacKeracher, and Katie Stella investigate the state of adult education in New Brunswick, a Canadian province they identify as "have-not". "The Impact of Globalization on Adult Education in a Have-Not Province" discusses the increasing unemployment rates and loss of long-established employment sources that New Brunswick is currently experiencing, which, combined with adults who are now in circumstances of having no clear employment direction has had a profound impact on adult education. They detail the shift the field has taken from an ethos of personal and social change toward a "neoliberal skills agenda."

Jennifer Sumner's article "Eating As If It Really Matters: Teaching The Pedagogy of Food in the Age of Globalization" chronicles a very important movement for adult education and globalization: the relationship between adult education, globalization and food. Sumner presents the development and teaching of a course in adult education that focused on eating as a pedagogical act and the nature of food as an important piece of a global dialogue.

Brock Education, Vol, 22, No. 2 Spring 2013, 1-2. 
Michelle K. McGinn, Snežana Ratković and Charl C. Wolhuter explore the current trend for internationalization of higher educational institutions through a study of academics in 19 countries. "Global Connectedness and Global Migration: Insights From the International Changing Academic Profession Survey" highlights the differences in global connectedness for academics working in their countries of birth referred to as "national academics" as compared to academics who are working in countries where they were not born referred to as "immigrant academics". These researchers found that participating academics demonstrated a high level of global connectedness in both their scholarship and their andragogy. Participants described their scholarship as "international in scope" and research collaborations with colleagues in other global contexts. However, the researchers also found that national academics were less globally connected than immigrant academics; thus leading the researchers to identify global migration by academics as a significant factor to internationalization of scholarship. This research highlights the significant internationalization contributions immigrant academics are making to their institutions both at home and abroad.

Jamie Magnusson's article "Precarious Learning and Labour in Financialized Time" compels us to consider the current globalized economic regimes and relations of learning and labour, debt, and the global economics of new wars and political turmoil. Although the risks are devastating for "youth, indigenous, working class and racialized women," currently there is little recognition of financialization for adult learners and in adult education. Magnusson's paper presents a discussion of the implications of financialized times in our contemporary period and offers a framework for examining how global realities can be addressed in sites of adult and higher education.

Matthew A. Eichler and Robert C. Mizzi's article "Negotiating the Confluence: MiddleEastern, Immigrant, Sexual-Minority Men and Concerns for Learning and Identity" presents case study research of three immigrant men re-locating from the Middle East to the United States and Canada. This case study frames the experiences of these men as they negotiate issues of identity, integration to their new societies and citizenship, learning, unmet expectations, and the complexities of becoming involved in sexual-minority settings. The authors assert that educational and social adult education programs should address these complex needs and issues for immigrant adult learners.

This issue concludes with May Al Fartousi's review Whose University Is It, Anyway? Power and Privilege on Gendered Terrain, edited by Anne Wagner, Sandra Acker, and Kimine Mayuzumi. Al Fartousi asserts that this book provides insight into equity issues in Canadian higher education. In a globalized world, an important query posed is: if equity can be achieved for all individuals but particularly those "whose identity is interwoven with gender, race, ethnicity, disability, social class, and religion and within various situational subjects (e.g., student, teaching assistants, faculty, and administrators) in a Canadian context."

Together the articles in the special issue provide a different vantage point through which to examine questions of adult education for whom and why? They advocate strongly for the importance of redressing social, institutional and political systems that disadvantage adult learners. The Brock Education readership may gain insights into how researchers featured herein both demand for the advancement of issues germane to social action - concerns that have been at the forefront of the adult education field as well as question the field for its omissions with reference to the globalized realities that inform learners lived experiences. In so doing these articles simultaneously draws attention to serious gaps in the research literature and by extension contribute to filling the identified omissions.

Brock Education, Vol, 22, No. 2 Spring 2013, 1-2. 